\title{
ANALYSIS OF VIBROTESTING DATA AND CAPILLAROSCOPY IN THE EMPLOYEES OF LOCOMOTIVE CREWS DEPENDING ON SENIORITY
}

Tkachyshyna N.Yu.

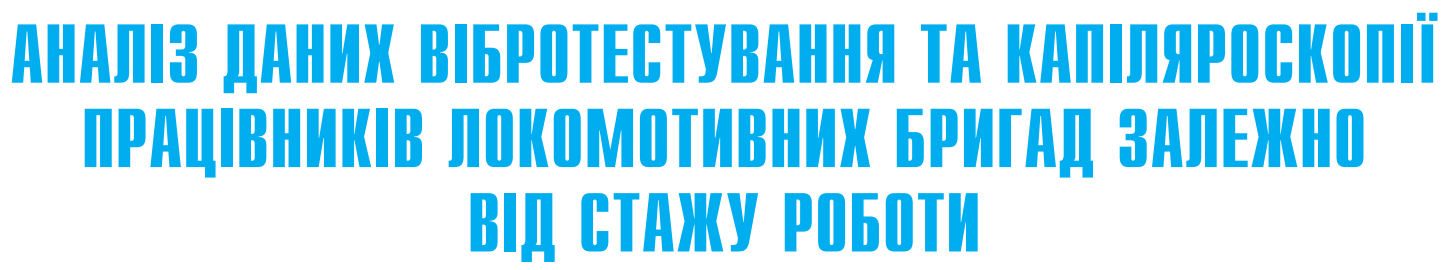

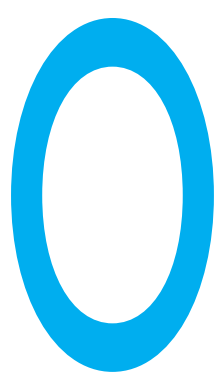

ТКАЧИШИНА Н.Ю.

ПАТ "УЗ" Філії "ЦОЗ"

Київська клінічна лікарня на залізничному транспорті № 2

УДК 613.02:613.644

Ключові слова: локомотивні бригади, стаж роботи, вібротестування, капіляроскопія. днією з основних професій на залізничному транспорті $€$ робота працівників локомотивних бригад (ПЛБ). Питання надійності людського чинника на транспорті стає особливо актуальним у зв'язку з підвищенням інтенсивності руху на усіх видах транспорту і реалізацією програми підвищення безпеки руху. На організм даної категорії працівників постійно впливає низка негативних виробничих факторів $[1,2]$, зокрема фактор емоційного та інтелектуального навантаження - шкідливість 2 ступеня (клас 3.2) та фактор вібрації - шкідливість 3 ступеня (клас 3.3). Отже, згідно 3 "Гігієнічною класифікацією праці за показниками шкідливості та небезпечності факторів виробничого середовища, важкост та напруженості трудового процесу" (затверджена наказом МОЗ України № 248 від 08.04.2014 р.) умови та характер праці Пль відносять загалом до 3 класу 3 ступеня (клас 3.3).

Згідно $з$ наказами № 246 М03 України і № 240 Міністерства транспорту та зв'язку ПЛБ регулярно проходять періодичні медичні огляди та ретельно обстежуються [3, 4].

Вібротестування $€$ одним із обов'язкових методів обсте- ження ПЛБ. Також було застосовано методику капіляроскопії. Зазначається, що мікросудинна дисфункція виявляється на початкових стадіях гіпертонічної хвороби, а до неї - при передгіпертонії. Тому дослідження мікросудинної функції може допомогти у ранньому виявленні, стратифікації ризику і у запобіганні термінальній стадії судинної патології в умовах впливу комбінованої вібрації [5].

Метою проведених нами досліджень стало вивчення вібраційної чутливості та стану мікроциркуляторного русла у ПЛБ залежно від стажу роботи.

Матеріали і методи. Загалом було обстежено 398 ПЛБ зі стажем роботи понад 1 рік та віком від 19 до 60 років.

Контрольною групою, що рандомізована за своїми основними параметрами (стать, вік, стаж роботи), слугували 116 інженерно-технічних працівників (ITП) Укрзалізниці. Ця категорія осіб, на відміну від ПлБ, не зазнає впливу комплексу негативних виробничих факторів: шуму, вібрації, дії електромагнітного поля, несприятливих мікрокліматичних умов, постійного нервового перенапруження, стресів, а також порушень режиму харчування та відпочинку
АНАЛИЗ ДАННЫХ ВИБРОТЕСТИРОВАНИЯ И КАПИЛЛЯРОСКОПИИ РАБОТНИКОВ ЛОКОМОТИВНЫХ БРИГАД В ЗАВИСИМОСТИ ОТ СТАЖА РАБОТЫ

Ткачишина Н.Ю.

ПАО "УЗ" филиала "ЦЗО" Киевская

клиническая больница на железнодорожном транспорте № 2

Нами обследовано 398 работников локомотивных бригад (РЛБ) и 116 инженерно-технических работников УЗ. Использованы методики вибротестирования и капилляроскопии. Результаты вибротестирования показали, что у РЛБ в первые 20 лет работы снижение порога вибрационной чувствительности выглядит как адаптация, а позже прогрессирует повышение порога чувствительности. При капилляроскопии нарушение микроциркуляции определяет тенденцию к повышенному артериальному давлению, чему способствует особенность труда РЛБ в условиях эмоционального и интеллектуального напряжения и наличия влияния комбинированной вибрации.

Ключевые слова: локомотивные бригады, стаж работы, вибротестирование, капилляроскопия.

ㄷ Ткачишина Н.Ю. СТАТТЯ, 2018. 
внаслідок чергування денних і нічних змін.

Розподіл за стажем у ПЛБ та ITП визначався за підгрупами (ПГ): від 1 до 10 років - ПГ1, від 11 до 20 років - ПГ2, від 21 до 30 років - ПГЗ, понад 30 років ПГ 4. Основна та контрольна групи співставні за стажем.

Вібротестування проводили за допомогою апарату "Вібротестер-МБН" ВТ-02-1 за стандартною програмою в автоматичному режимі на частотах $63,125,250$ Гц. Проводився аналіз показників правої руки.

Оцінка стану капілярів і капілярного кровотоку здійснювалася за допомогою методу капіляроскопії нігтьового ложа за допомогою апарату "Капіляроскоп М-70", що дає збільшення у 70 разів. Проводили капіляроскопію IV пальця лівої руки з нанесенням на шкірну складку нігтьового ложа краплі персикової олії для гомогенізації поверхневого епідермального шару.

Результати та обговорення. За результатами вібротестування складено таблицю 1.

При аналізі отриманих показників бачимо: у ПГ1 показники віброчутливості у ПЛБ нижче нульової відмітки і становлять на різних частотах $(-1,50 \pm 0,25)$, $(-4,55 \pm 1,50)$ та $(8,50 \pm 2,55)$. у ПГ2 тенденція до підвищеної чутливості навіть збільшується відповідно за частотами і становить $(-5,25 \pm 1,50),(6,75 \pm 1,55)$ та $(-8,50 \pm 2,55)$. А вже у ПГЗ чутливість зменшується та становить $(+1,75 \pm 0,25), \quad(+2,75 \pm 0,50)$ та $(+4,25 \pm 1,50)$ відповідно на означених частотах. У ПГ4 ПЛБ ця тенденція до зниження чутливості стає виразнішою, але вібраційна чутливість у ПЛБ зберігається у допустимих межах і становить $(+8,10 \pm 1,75)$, $(+6,75 \pm 1,50)$ та $(+12,50 \pm 1,25)$

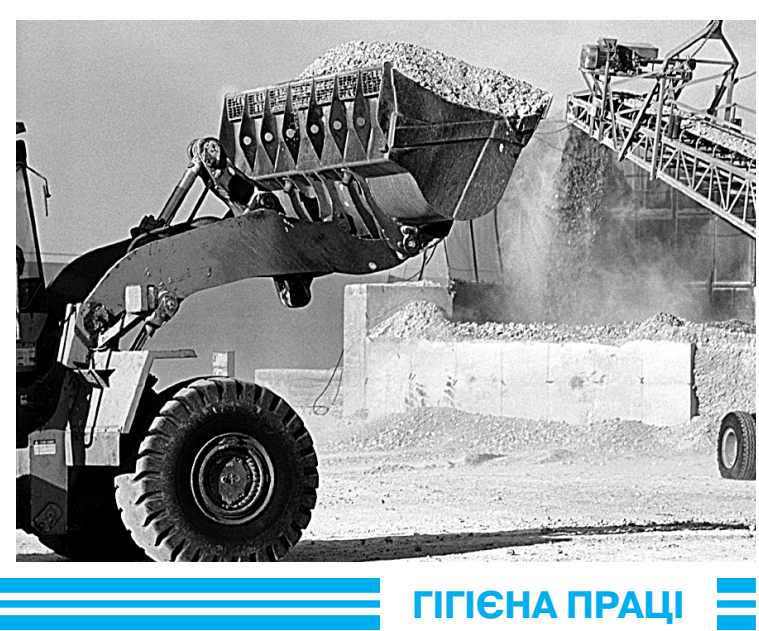

відповідно. Отже, вібраційна хвороба як нозологічна одиниця в обстежених ПЛБ не виявляється.

Зниження порогів вібраційної чутливості вказує на підвищену чутливість вібраційного аналізатора та відзначається частіше в осіб з функціональними розладами нервової системи. у випадку з ПлБ має місце подразнюючий вплив низки факторів, з якими стикаються на роботі працівники даної професійної групи, що призводить до підвищення щільності рецепторів, які реагують на вібрацію, на пальцях рук.

У перші 20 років роботи зниження порогу вібраційної чутливості виглядає як адаптація, а вже пізніше має місце тенденція до підвищення порогу чутливості.

Підвищення порогів вібраційної чутливості більше стандартних показників здорової людини розглядається як зниження вібраційної чутливості та спостерігається при розвитку таких професійних захворювань, як вібраційна хвороба, вегетосенсорна полінейропатія верхніх кінцівок від комплексу виробничих факторів, а також при різних загальних захворюваннях нервової системи функціонального та органічного походження.
Як видно з таблиці 1, після 21 року стажу у багатьох ПЛБ відмічається тенденція до зниження чутливості. Отже, після 21 року стажу у ПЛБ відбуваються зміни, які вказують на певний зв'язок стану капілярної системи верхніх кінцівок та їхньої чутливості. А це свідчить про зниження адаптаційного потенціалу організму та виникнення морфологічної трансформації функціонального порушення ССС внаслідок хронічного стресу і надлишкового впливу симпатоадреналової системи на організм, які присутні у професійній діяльності ПЛБ.

у контрольній групі виявляється, що у ПГ1 ІТП картина віброчутливості на кожній 3 частот подібна такій, яка має місце у групі ПЛБ. У Пг2 тоді, як у ПЛБ віброчутливість підвищується, в ITП незначно знижується і надалі зберігає подібну тенденцію, залишаючись у межах норми.

У ПЛБ картина змін набуває хвилеподібного характеру, як описано вище: у групі зі стажем до 20 років чутливість збільшується, у ПГЗ - зменшується, а у ПГ4 зниження чутливості стає більш вираженим, ніж у контрольній групі. Характер змін однотипний для усіх частот.

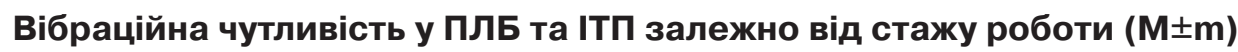

Таблиця 1

\begin{tabular}{|c|c|c|c|c|c|c|}
\hline \multirow{3}{*}{$\begin{array}{l}\text { Стаж, } \\
\text { років }\end{array}$} & \multicolumn{6}{|c|}{ Частота вібрації Гц } \\
\hline & \multicolumn{2}{|c|}{63} & \multicolumn{2}{|c|}{125} & \multicolumn{2}{|c|}{250} \\
\hline & ПЛБ & ITП & ПЛБ & ITП & ПЛБ & ITח \\
\hline ПГ1 & $-1,50 \pm 0,25$ & $-2,85 \pm 0,28$ & $-4,55 \pm 1,50$ & $-4,32 \pm 1,57$ & $-8,50 \pm 2,55$ & $-7,12 \pm 3,06$ \\
\hline ПГ2 & $-5,25 \pm 1,50$ & $-2,02 \pm 0,78$ & $-6,75 \pm 1,55$ & $-2,97 \pm 1,25$ & $-9,75 \pm 2,50$ & $-5,31 \pm 1,89$ \\
\hline ПГЗ & $+1,75 \pm 0,25$ & $-1,75 \pm 0,37$ & $+2,75 \pm 0,50$ & $+0,15 \pm 0,18$ & $+4,25 \pm 1,50$ & $+1,25 \pm 0,38$ \\
\hline ПГ4 & $+8,10 \pm 1,75^{\star \circ}$ & $+2,57 \pm 0,54$ & $+6,75 \pm 1,50^{* \circ}$ & $+3,21 \pm 0,96$ & $+12,50 \pm 1,25^{\star \circ}$ & $+5,18 \pm 1,12$ \\
\hline
\end{tabular}

Примітка: * - різниця достовірна між аналогічними показниками четвертих стажових груп ПЛБ та ITП $(p<0,05)$;
- різниця достовірна між аналогічними показниками четвертої та першої стажових груп ПЛБ $(p<0,05)$. 
Для оцінки структурних змін на мікрорівні було проведено капіляроскопію (табл. 2).

При аналізі даних таблиці загальна видимість капілярів добра в обох групах у 100\% обстежених осіб.

Фон у ПЛБ переважно блідорожевий, який зустрічається у $(88,19 \pm 1,62) \%$, a y $(11,81 \pm$ $1,62) \%$ - рожево-червоний. У контрольній групі показники відрізняються недостовірно: блідо-рожевий фон характерний для $(91,38 \pm 2,61) \%$, а рожево-червоний зустрічається у $(8,62 \pm 2,61) \%$ обстежених працівників.

За кількістю капілярів у полі зору у $(80,40 \pm 1,99) \%$ ПЛБ та у $(87,07 \pm 3,11) \%$ осіб контрольної групи їхня кількість - 1520 , а у $(19,60 \pm 1,99) \%$ ПЛБ та у $(12,93 \pm 3,11) \%$ ІТП кількість капілярів вже 20-25 у полі зору, тобто збільшується в обох групах, але різниця не $\epsilon$ достовірною.

Щодо довжини капілярів, то в обох групах подовжені капіляри візуалізуються у 100\%, а вкорочені не зустрічаються.

За формою прямі, тобто незмінені, капіляри в основній групі зустрічаються у $(65,83 \pm$ $2,38) \%$, а у контрольній - у $(88,79 \pm 2,93) \%$, різниця достовірна $(p<0,05)$. Змінені капіляри в основній групі зустрічаються у такому розподілі: помірно звивисті - у $(26,88 \pm$ $2,22) \%$ та звивисті спіралепо-

\section{Дані капіляроскопії у ПЛБ та ITП у відносних значеннях $(P \pm m p)$}

\begin{tabular}{|l|c|c|c|}
\hline Показник & Характеристика & ПЛБ $(\mathrm{n}=398)$ & IТП $(\mathrm{n}=116)$ \\
\hline \multirow{3}{*}{ Видимість } & добра & 100 & 100 \\
\cline { 2 - 4 } & погана & 0 & 0 \\
\hline \multirow{3}{*}{ Кількість } & блідий & 0 & 0 \\
\cline { 2 - 4 } & блідо-рожевий & $88,19 \pm 1,62$ & $91,38 \pm 2,61$ \\
\cline { 2 - 4 } & $10-15$ & $11,81 \pm 1,62$ & $8,62 \pm 2,61$ \\
\hline \multirow{3}{*}{ Довжина } & $20-25$ & 0 & 0 \\
\cline { 2 - 4 } & подовжені & $19,40 \pm 1,99$ & $87,07 \pm 3,11$ \\
\hline \multirow{3}{*}{ Форма } & вкорочені & 0 & $12,93 \pm 3,11$ \\
\cline { 2 - 4 } & помямі & $65,83 \pm 2,38$ & $88,79 \pm 2,93$ \\
\cline { 2 - 4 } & Звивисті, спіралеподібні & $7,29 \pm 1,30$ & 100 \\
\hline \multirow{3}{*}{ Діаметр } & нормальний & $73,87 \pm 2,20$ & $89,65 \pm 2,83$ \\
\cline { 2 - 4 } & Зменшений (зморщені) & $26,13 \pm 2,20$ & $10,35 \pm 2,83$ \\
\cline { 2 - 4 } & Збільшений (роздуті) & 0 & 0 \\
\hline
\end{tabular}

взагалі не спостерігається. У ПГ2 у $(5,95 \pm 2,58) \%$ фон стає рожевим/червоним, а у ПГЗ кількість ПЛБ з рожевим/червоним фоном зростає і зустрічається у $(21,14 \pm 3,70) \%$ за наявності блідо-рожевого фону у $(79,86 \pm 3,70) \%$. У ПГ 4 у $(20,73 \pm 4,48) \%$ фон $€$ рожевим/червоним. Тобто достовірна різниця $(p<0,05)$ у зміні фону виявляється вже між групами ПГ2 та ПГЗ. У групі ІТП збільшення відсотка осіб з рожевим/червоним фоном реєструється $3 \quad(3,85 \pm 3,77) \%$ у ПГ2 до $(8,57 \pm 4,73) \%$ у ПГЗ, до $(11,54 \pm 6,26) \%-$ - ПГ 4 .

щодо оцінки кількості капілярів у ПГ1 у ПЛБ та ІТП різниці немає: кількість капілярів у межах 15-20. у пль у Пг2 за результатами спостереження виявляється збільшення їх 3 15-20 до 20-25 у $(10,71 \pm$ $3,37) \%$, у ПГЗ - $(35,77 \pm 4,32) \%$, у ПГ 4 - у $(40,24 \pm 5,42) \%$. У групі ІТП кількість тих, у кого має місце збільшення капілярів до 20-25 у полі зору, у ПГ2 зустрічається у $(10,71 \pm 3,3788) \%$, у ПГЗ - у $(14,29 \pm 5,91) \%$, у ПГ 4 - у $(19,23 \pm 7,73) \%$. При порівнянні показників у ПГЗ обох груп різниця $є$ достовірною $(p<0,05)$. Достовірність зберігається й надалі у ПГ 4

При оцінці форми у ПЛБ у ПГ1 значно переважали прямі капіляри і становили $(90,77 \pm$ $2,77) \%$, але зустрічалися й помірно звивисті, що становили $(9,23 \pm 2,77) \%$. У ПГ2 кількість помірно звивистих збільшилася до $(16,13 \pm 4,01) \%$. У ПГЗ помірно звивисті капіляри спостерігались у $(35,77 \pm$ $4,32) \%$, а також з'являлися звивисті, спіралеподібні капіляри, кількість яких склала $(12,20 \pm 2,95) \%$. Процес зміни форми капілярів ще більше проявляється у ПЛБ у ПГ4, де помірно звивисті капіляри зустрічались у $(40,25 \pm 5,42) \%$, а звивисті, спіралеподібні - у $(14,63 \pm 3,90) \%$. у ІТП у ПГ1 прямі капіляри були у $(93,10 \pm$ $4,71) \%$, а помірно звивисті - у $(6,90 \pm 4,71) \% ;$ у ПГ2 прямі - у $(88,46 \pm 6,26) \%$, а помірно звивисті - у $(11,54 \pm 6,26) \%$; у ПГЗ прямі - у $(71,43 \pm 7,64) \%$, а помірно звивисті - у $(28,57 \pm$ $7,64) \%$. І в ІТП у ПГ 4: прямі - у $(57,69 \pm 9,69) \%$, помірно звивисті - у $(38,46 \pm 8,11) \%$, звивисті, спіралеподібні - у $(3,85 \pm$ $3,77) \%$. Отже, у ПЛБ та ITП у ПГ1 і ПГ2 різниці немає, а у ПГЗ 
ANALYSIS OF VIBROTESTING DATA AND CAPILLAROSCOPY IN THE EMPLOYEES OF LOCOMOTIVE CREWS DEPENDING ON SENIORITY

Tkachyshyna N.Yu.

Kyiv Clinical Hospital at Railway Transport № 2, "HC" Branch, PC "UR", Ukraine

We examined 398 workers of locomotive crews (WLC) and 116 engineers and technicians of the UR. We used the methods of vibration testing and capillaroscopy.
The results of vibration testing showed that in the first 20 years of work, a decrease of the threshold of vibration sensitivity looked like an adaptation, and later an increase of the sensitivity threshold progressed. At capillaroscopy, the violation of microcirculation determines a tendency to increased arterial pressure, it is favoured by the peculiarity of the labour of the WLC under conditions of emotional and intellectual tension and combined vibration effect.

Keywords: locomotive crews, seniority, vibration testing, capillaroscopy. та ПГ4 різниця достовірна $(p<0,05)$.

Щодо оцінки діаметра капілярів, то маємо таку картину. Зменшений діаметр вже фіксувався у ПЛБ у ПГ1 і становив $(6,42 \pm 2,35) \%$, у ПГ2 - у $(10,71 \pm$ 3,37)\%, у ПГЗ - у $(34,15 \pm 4.28) \%$, у ПГ 4 - у $(53,66 \pm 5,26) \%$. У ITП зменшених капілярів у ПГ1 не виявлено, у ПГ2 зустрічаються у $(3,85 \pm 3,77) \%$, у ПГЗ - у $(17,15$ $\pm 6,37) \%$, у ПГ - - $(34,62 \pm 9,33) \%$.
В осіб контрольної групи капіляри нігтьового валика мають петлеподібну форму 3 артеріальним, перехідним і венозним колінами. Капіляри розташовуються більш-менш правильними рядами, закінчуються на одному рівні. Стінка капілярів рівна, лише іноді злегка звите перехідне коліно, кровонаповнення добре, однакове в усіх петлях; рух крови рівномірний, уповільнений у місці переходу артеріальної частини капіляра у венозну. Колір капілярів інтенсивно червоний. Розташовуються вони рядами, у вигляді частоколу, у кілька поверхів. У групі ПЛБ картина інша: визначається незначна каламутність фону. Капіляри набувають форми вісімки, стають звивистими або спіралеподібними. У більшості спостерігається зменшення діаметра капіляра. У цих

Дані капіляроскопії у ПЛБ та ITП у відносних значеннях (P \pm mp)

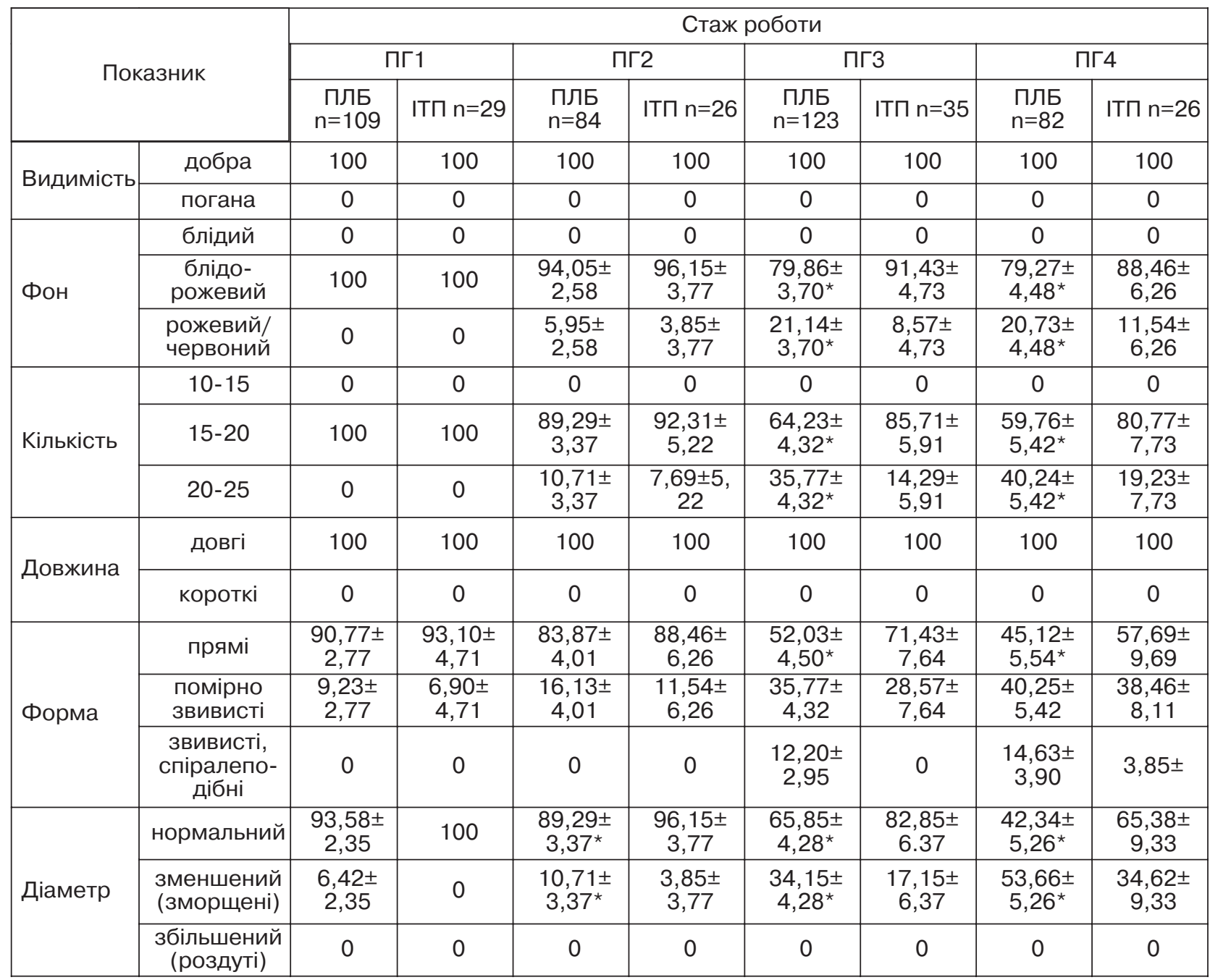

Примітка:

* - різниця достовірна між аналогічними показниками обстежених груп в одній ПГ $(p<0,05)$. 
випадках вони мають іноді вигляд обривків, ком, крапок. Розташування їх стає дещо безсистемним, густішим. Рух крови у капілярах сповільнюється або стає переривчастим. При цьому видно навіть проходження окремих еритроцитів. Створюється враження, що кров у ПЛБ густіша. Отже, за нашими даними, основними капіляроскопічними ознаками змін судин мікроциркуляторного русла у ПЛБ є зміни розмірів, форми, кількості та діаметра капілярів. Таким чином, внаслідок хронічного підвищення тонусу симпатоадреналової системи у ПЛБ зі збільшенням стажу роботи спостерігається хронічний спазм судин і зростає периферичний опір. Останне зі збільшенням стажу роботи призводитиме до перевантаження лівого шлуночка серця.

Враховуючи вищевказане, спостерігаємо відносне підвищення АТ у групі ПЛБ порівняно з ІТП. Згідно $з$ таблицею після 20-ти років стажу у багатьох ПЛБ капіляри стають звивистими, спіралеподібними, "зморщеними", їхня кількість у полі зору зростає до 20-25 штук, а фон стає рожевим/червоним. Це свідчить про вичерпання адаптаційного потенціалу організму та прояви морфологічної трансформації функціонального порушення ССС внаслідок хронічного стресу і надлишкового впливу симпатоадреналової системи на організм. Отже, капіляроскопічний метод дозволяє виявити ознаки порушення кровообігу значно раніше, ніж вони проявляються клінічно. У початковому періоді у ПЛБ такі зміни зведені то до сповільнення, то до прискорення кровотоку, який іноді робиться переривчастим, формуючи звивистість та спіралеподібність капілярів.

Пізніше фон стає рожевочервоним внаслідок збільшення кількості капілярних петель, звуження артеріальної та розширення венозної частини, появи атипових капілярів, що ми і бачимо при вивченні показників капіляроскопії залежно від стажу.

1. При вібротестуванні у ПЛБ встановлено, що віброчутливість у них зі збільшенням стажу набуває хвилеподібного характеру: у ПГ2 чутливість збільшується, у ПГЗ - зменшується порівняно з ПГЗ ІТП, а у ПГ4 зниження чутливості стає достовірно $(p<0,05)$ більшим, ніж у контрольній групі. у випадку з ПЛБ має місце подразнюючий вплив низки факторів трудового процесу, що призводить до підвищення щільності рецепторів, які реагують на вібрацію, на пальцях рук. У перші 20 років роботи зниження порогу вібраційної чутливості виглядає як адаптація, а вже пізніше має місце тенденція до підвищення порогу чутливості.

2. Після 20 років стажу у достовірно $(p<0,05)$ більшого відсотка ПЛБ на відміну від ІТП капіляри стають звивистими, спіралеподібними, "зморщеними", діаметр їх зменшується, кількість у полі зору зростає до 20-25 штук, а фон у кожного 5-го стає рожевим/червоним. Така картина на рівні капілярів характеризує порушення функціонування системи мікроциркуляції та визначає тенденцію до підвищеного АT, чому сприяе особливість роботи ПЛБ за умов присутності факторів емоційного та інтелектуального навантаження.

ЛІТЕРАТУРА

1. Вильк М. Ф., Капцов В.А., Коротич Л.П., Викторов В.С., Тулушев В.Н. Особенности оценки профессионального риска работников железнодорожного транспорта. Сборник материалов XI Всероссийского конгресса "Профессия и здоровье". М., 2012. С. 118-120.

2. Жижневская А.А., Лисо-

бей В.А. О взаимосвязи заболеваемости машинистов железнодорожного транспорта и их помощников с условиями труда. Актуальные проблемы транспортной медицины. 2006. № 3 (5). C. $69-73$.

3. Про затвердження Порядку проведення медичних оглядів працівників певних категорій залізничного транспорту, метрополітенів та підприємств міжгалузевого промислового залізничного транспорту України : наказ Міністерства транспорту та зв'язку України від 29.04.2010 p. № 240. URL : http://zakon2.rada.gov.ua/ laws/show/z0537-10

4. Про затвердження Порядку проведення медичних оглядів працівників певних категорій : наказ Міністерства охорони здоров'я України від 21.05.2007 р. № 246. URL : http://zakono.rada.gov.ua/laws/ show/z0846-07

5. Ткачишин В.С. Професійні хвороби. К. : Інформаційноаналітичне агентство, 2011. 895 c.

REFERENCES

1. Vilk M.F., Kaptsov V.A., Korotich L.P., Viktorov C.S. and Tulushev V.N. Osobennosti otsenki professionalnogo riska rabotnikov zheleznodorozhnogo transporta [Features of the Professional Risk Assessment of the Railway Transport Workers]. In : Sbornik materialov XIV Vserossiyskogo kongressa "Professiya i zdorovie"

[Collection of the Materials of the XI All-Russian Congress "Profession and Health"]. Moscow ; 2012 : 118-120 (in Russian).

2. Zhizhnevskaya A.A. and Lisobey V.A. Aktualnye problem transportnoy meditsiny. 2006 ; № 3 (5) : 69-73 (in Russian).

3. Pro zatverdzhennia Poriadku provedennia medychnykh ohliadiv pratsivnykiv pevnykh katehoriy zaliznychnoho transportu, metropoliteniv ta pidpryiemstv mizhhaluzevoho promyslovoho zaliznychnoho transport Ukrainy : nakaz Ministerstva transport ta zviazku Ukrainy vid 29.04.2010 roku № 240 [On the Adoption of the Order of Medical Examinations in the Employees of Certain Categories of Railway Transport, Subway, and Enterprises of Interindustrial Railway Transport of Ukraine : Order of the Ministry of Transport and Communications № 240, April 29, 2010]. URL : http://zakon2.rada.gov. ua/laws/show/z0537-10

(in Ukrainian).

4. Pro zatverdzhennia Poriadku provedennia medychnykh ohliadiv pratsivnykiv pevnykh katehoriy [On the Adoption of the Order of Medical

Examinations in the Employees of Certain Categories : Order of the Ministry of Public Health of Ukraine № 246, 21.05.2007].

URL : http://zakon0.rada. gov.ua/laws/show/z0846-07 (in Ukrainian).

5. Tkachyshyn V.S. Provesiini khvoroby [Occupational Diseases]. Kyiv : Informatsiinoanalitychne ahenstvo ; 2011 : 895 p. (in Ukrainian).

Надійшло до редакції 17.11.2017 